\title{
ANALYTICAL TREATMENT OF FORECASTS OF ELECTRIC ENERGY CONSUMPTION IN LATVIA
}

\author{
M. Balodis, V. Gavars, J. Andersons \\ J/S Co „Latvenergo” \\ 12 Pulkveža Brieža Str., Rīga, LV-1230, LATVIA
}

\begin{abstract}
In the paper, the changes in electric energy consumption are analyzed as associated with structural changes in the Latvian economy of postsocialistic period. To the analysis, a particular approach is applied, which consists in comparison of the basic and specific electricity consumption indices in West-, Central-, and East-European states for the time span of 1990-2010, with differences and tendencies of changes revealed. Tendencies of the type are determined for the electric energy consumption in Latvia, and recommendations are given for the use of such indices in the relevant forecasts.
\end{abstract}

Keywords: electricity consumption forecasts, electricity consumption in Latvia, electricity consumption in EU states, basic and specific indices.

\section{INTRODUCTION}

According to the centralized planning of Soviet Union, the character of GDP growth was uninterruptedly ascending - almost linear. At the end of the IX fiveyear planning term, in 1975 the electricity consumption reached 1,036 TWh, from which $57 \%$ was consumed by industry, $9 \%$ - by transport and civil engineering, $12 \%$ - by inhabitants and services, $7 \%$ - by the agricultural sector, and $15 \%$ was the self-consumption of energy economy and losses. When Latvia was a USSR member-republic, its energy economy planning followed the five-year pattern adopted in the entire Soviet Union. The Latvian SSR was included into the USSR North-West region, for which the common electricity consumption plans were worked out and controlled.

The year 1973. At the preparation of the 10th five-year plan a deep-rooted correlation was taken into account which implies that the electricity consumption is rising linearly similar to GDP. For the Latvian territory the following electricity output was planned: in $1980-6.5 \mathrm{TWh}$; in $1985-8.4 \mathrm{TWh}$, but in $1990-29.9$ TWh, i.e., considerably exceeding the needs of our country. In the plan, the nuclear power plant at Pavilosta (6000 MW) was included, which was intended for supplying the North-Western region of the USSR with electricity. The consumption in the Latvian SSR was planned to be $10 \mathrm{TWh}^{1}$ (see Table 1). The Latvian SSR State Planning Committee raised objections against construction of the Pavilosta NPP, so this was not approved.

\footnotetext{
${ }^{1}$ The letter of USSR Energy Ministry of 29.05.1973, Nr.8/3233
} 
The year 1975. The Leningrad Planning Institute Энергосетьпроект put forward a proposal to the Latvian SSR State Planning Committee and Latvenergo for the energy development in Latvia up to $1990^{2}$. The corresponding forecasts were composed taking into account that the electricity consumption should be basically determined by two criteria. First of them was a complex economy criterion comprising such factors as the specific value of capital investments (rouble $/ \mathrm{kW}$ ), electric energy cost (rouble/MWh) and some others, while the second criterion characterized the safety of electricity supply as related to the nuclear energy. The site for a 6000 NPP was chosen at Pavilosta (Latvia). Putting into operation of its first block (1000-1500 MW) was planned for 1989-1990. The planned electricity output is shown in Table 1.

The year 1981. The Energy and Electrification Ministry of the USSR defined the objectives for the North-West Dispatcher Centre (DC) ${ }^{3}$. The DC was located in Riga, its duties were to set up the operational regimes for power plants and coordinate the power supply to Latvia, Lithuania, Estonia, Belarus, Karelia, as well as to the Leningrad and Kaliningrad regions. More than $2000 \mathrm{~km}$ long high-voltage lines connected the system's power plants. For the year 2000 the electric energy consumption of 17.5 TWh (Table 1) and the load of $3600 \mathrm{MW}$ were forecasted. To ensure the demand, it was necessary to construct in the territory of Latvian SSR a nuclear power plant which would give output of 4000 MW by 2000 .

The year 1988. Latvenergo carried out investigation of alternative variants for electrification of Latvia based on the electricity consumption forecasts made by the Institute of Physical Energetics (Latvian Academy of Sciences) and the planning institute „Latgiproprom” (Table 1). It should be noted that in Soviet times in the energy plans the total (gross) consumption was shown - i.e. including the self-consumption of power plants. To meet this demand, four variants were considered: a coal station (2000 MW), an NPP (2000 MW), and two variants with the use of gas (2400 MW). As the best, a gas-fired plant was adopted, which would be built and used together with the Inchukalns gas storage. In perspective, to satisfy the demand the construction of an NPP in the territory of the Latvian SSR was envisaged (see Table 1).

In this paper, the basic and specific indices of electricity consumption are analyzed and compared with those adopted in EU, and the tendencies of their changes in the relevant Latvian forecasts are shown.

\section{LATVIAN ENERGY CONSUMPTION FORECASTS AFTER RESTORATION OF INDEPENDENCE}

\subsection{The State Energy Programme of the Latvian Republic (1992)}

After the restoration of Latvian State independence, the target set for the new Energy Ministry was to work out the first energy programme [1]. In Part 4 of the programme the demand for electric energy was defined. In this and the following programmes the electricity output was indicated (without self-consumption by power plants). It was of primary importance to elaborate a relevant plan, since the Latvian power plants did not cover the demand, and the electricity was imported.

\footnotetext{
${ }^{2}$ The letter of the Planning Institute Энергосетьпроект of 10.02.1975, Nr.11-10cp

${ }^{3}$ The letter of the North-West Dispatcher Centre of 1981, Nr.6-13.7/798
} 


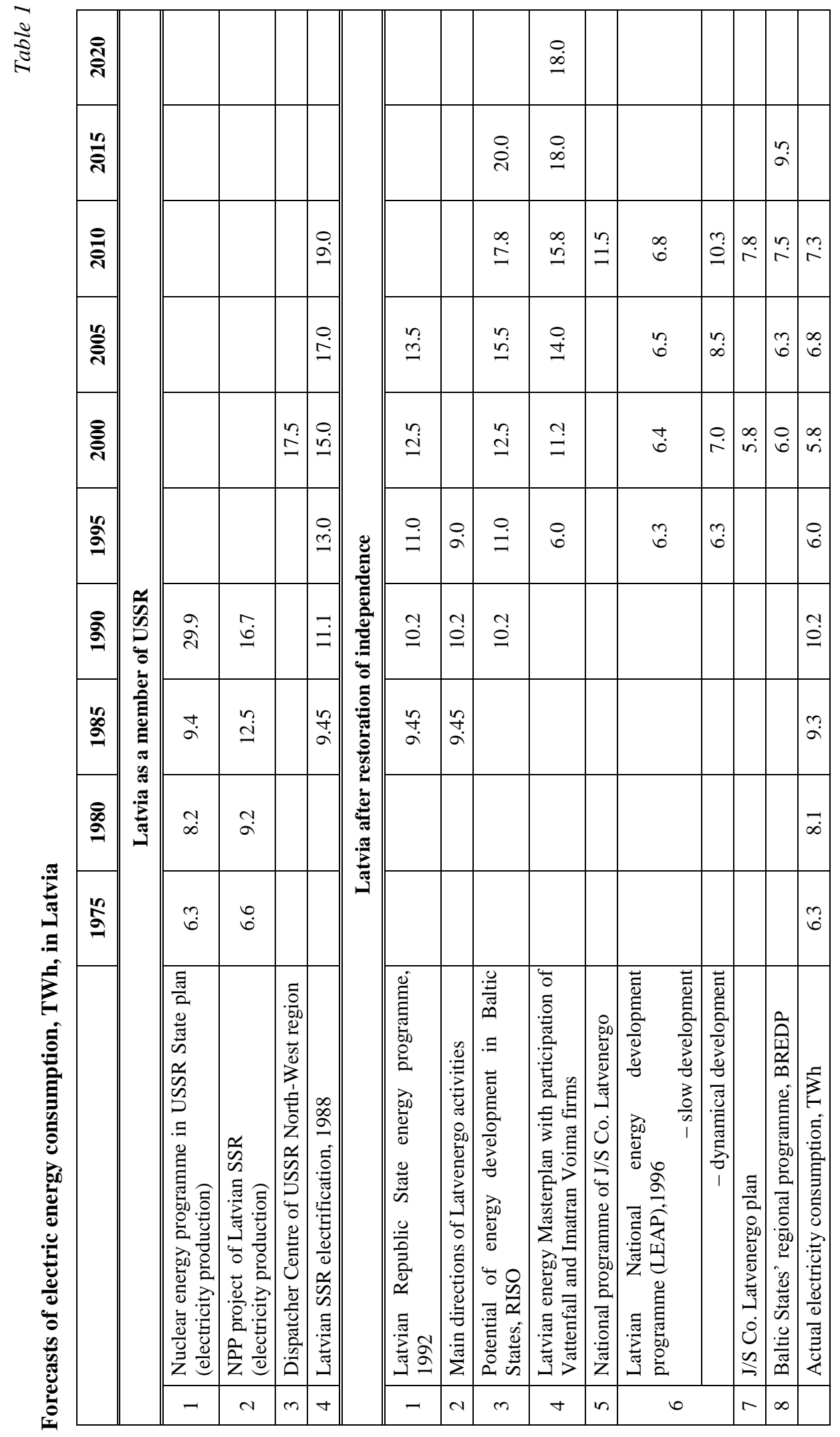


At the beginning of the new century it was planned to raise the output up to 12.5 TWh. In the programme it was envisaged that the import would be necessary up to 2003 (see Table 1).

\subsection{Main directions of Latvenergo activities up to 1996}

In compliance with the State Energy Programme of 1992, the J/S Co. Latvenergo worked out the main directions for its activities for the succeeding years. It should be noted that no consumption growth was then expected until 1996 (Table 1).

\subsection{Energy development potential of Latvia, Lithuania, and Estonia}

In 1992, the consultant firm RISO of Denmark National Laboratory carried out investigation into the energy supply in Baltic States, and estimated also the Latvian potential of the energy economy (Table 1) [2]. In this estimation it was implied that the Liepāja's factory „Sarkanais Metalurgs" would update technology and raise substantially the electric energy consumption.

\subsection{Latvian energy development programme}

After the restoration of independence in Latvia a rapid re-orientation of National Economy occurred (however not taken into account in the first energy programme). In 1994, the Latvian specialists, in cooperation with the experts from Vattenfal $A b$ and Imantran Voima $O y$, worked out a new energy development programme - Masterplan. The programme envisaged that by 2010 the Latvian power plants would be capable of covering the demand for electricity by $85 \%$. In the programme three scenarios were considered, according to which the expected electricity consumption in 2010 would reach 14.7 TWh, 12.5 TWh (Table 1) and 10.3 TWh. Among the consumers' groups the demand would be allocated in the following way: industry $-41 \%$, services $-20 \%$, households $-20 \%$, agriculture $15 \%$, and transport $-4 \%$.

\subsection{J/S Co. Latvenergo programme of energy development (1994)}

In compliance with the Masterplan programme, in 1994 the $\mathrm{J} / \mathrm{S}$ Co. Latvenergo worked out its development programme which envisaged that in 2010 the consumption would be 11.5 TWh (see Table 1). To cover the increasing demand for electricity it was necessary to raise the Riga TEC-2 capacity up to 500 MW and to construct the Liepaja TES (300 MW). The possibility was considered for building an AP 600 type NPP after the year 2010.

\subsection{The Latvian National Programme of Energy Development (LEAP)}

Taking into account unexpectedly rapid changes in the situation with energy supply in the state, by the order of the Cabinet of Ministers Nr.162-r in 1994 a new National Energy Programme was worked out. This was done at the Riga Technical University with participation of others Latvian experts. The programme was based on the GDP forecast of slow and dynamical development made by the Ministry of Economy in 1996 as well as on the electric energy consumption forecast made by 
the World Bank (Table 1). At the programme elaboration the forecast of the average realization tariffs on electricity was used, which was made by the Norwegian firm "NORPLAN". This forecast envisaged that from 1996 to 2010 the average electricity price for the end users would rise four-fold.

\subsection{The Investment Plan of J/S Co. Latvenergo for 1999 - 2010}

The plan was worked out in 1999 by Latvenergo. For the realized forecasts of electricity consumption the programme ENERGY 2020 was used. In this programme, particular attention was given to the changes in the GDP/electricity consumption distribution by branches (Table 2 ).

Distribution of electricity consumption by branches in 2010

Table 2

\begin{tabular}{|l|c|c|c|c|c|}
\hline & \multirow{2}{*}{$\begin{array}{c}\text { Latvian } \\
\text { actual, 1990 }\end{array}$} & \multirow{2}{*}{$\begin{array}{c}\text { Energy 2020 } \\
\text { planned for } \\
\text { Latvia 2010 }\end{array}$} & \multicolumn{3}{|c|}{ Actual consumption in 2010 } \\
\cline { 4 - 6 } & $45 \%$ & $39 \%$ & $24 \%$ & $34 \%$ & $40 \%$ \\
\hline Industry & $19 \%$ & $30 \%$ & $39 \%$ & $36 \%$ & $31 \%$ \\
\hline Services & $15 \%$ & $25 \%$ & $31 \%$ & $28 \%$ & $23 \%$ \\
\hline Households & $19 \%$ & $3 \%$ & $3 \%$ & $4 \%$ & $3 \%$ \\
\hline Agriculture & $2 \%$ & $3 \%$ & $3 \%$ & $3 \%$ & $3 \%$ \\
\hline Transport & $100 \%$ & $100 \%$ & $100 \%$ & $100 \%$ & $100 \%$ \\
\hline Total & & & & & Lithuania \\
\hline
\end{tabular}

For comparison, in Table 2 the actual electricity consumption by branches in Lithuania and Estonia is also shown [3]. In this table it is seen that in 2010 the electricity consumption in Latvia decreased in industry while increased in service sector as compared with planned by the Energy 2020 programme. In Estonia, the actual consumption by industry is greater since the fall in the electricity consumption after 1990 was there smaller than in Latvia.

\subsection{Baltic Regional Energy Development Programme (BREDP), 1999.}

Elaboration of the programme was financed by the USA International Development Agency ${ }^{4}$.

In the work, the representatives from the DC Baltija as well as from Estonia, Latvia, and Lithuania took part. In this programme, the planned growth of GDP was used in the dynamical and the moderate economic development variants. In the former, this growth was to be from 5\% to $6 \%$, while in the latter - from $3 \%$ to $4 \%$; accordingly, the expected electricity consumption was forecasted (see Table 1 and Fig. 1).

${ }^{4}$ USAID Letter of Intent of April 5, 1994. 


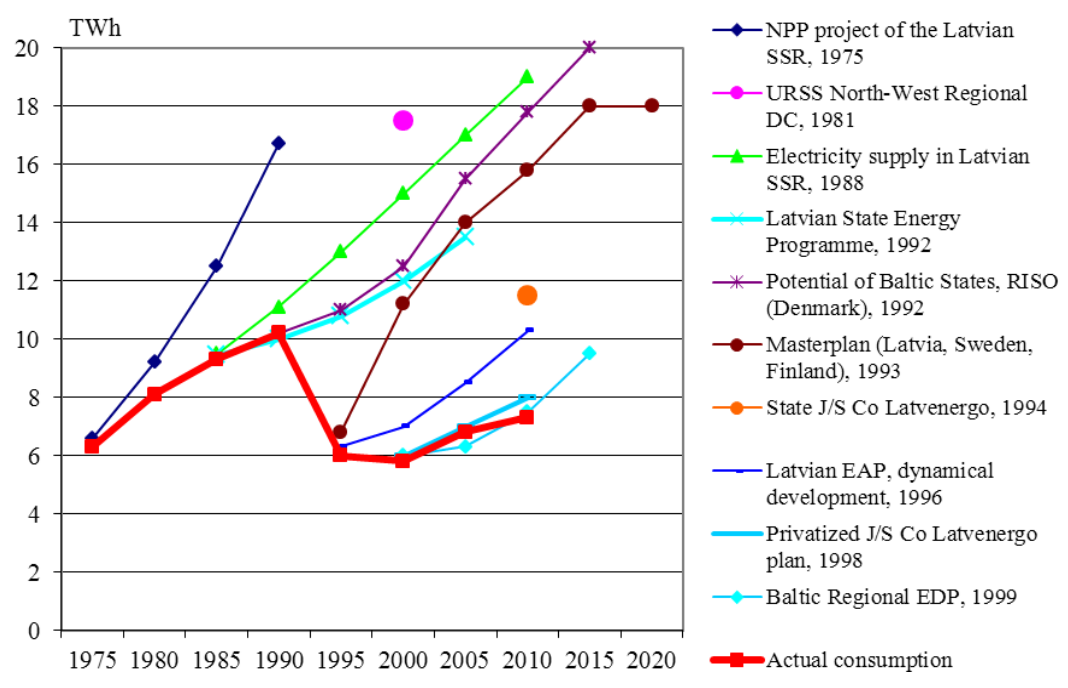

Fig. 1. Latvian electricity consumption in forecasts and in reality.

\section{ANALYSIS OF LATVIAN ELECTRICITY SUPPLY FORECASTS}

In the most part, the Latvian electricity consumption forecasted for the time period (1975-2010) differs considerably from the actual.

It should be stressed that one of the primary criteria of electricity consumption is the GDP development in the state. This criterion is used in all relevant forecasts. Analysis of the actual electricity consumption values shows a noticeable GDP influence on these values, especially in the times of economic restructuring. Figure 2 shows the changes in the Latvian electricity consumption as correlating with those in GDP. The changes in the former and in the latter are not proportional in different time periods [4].

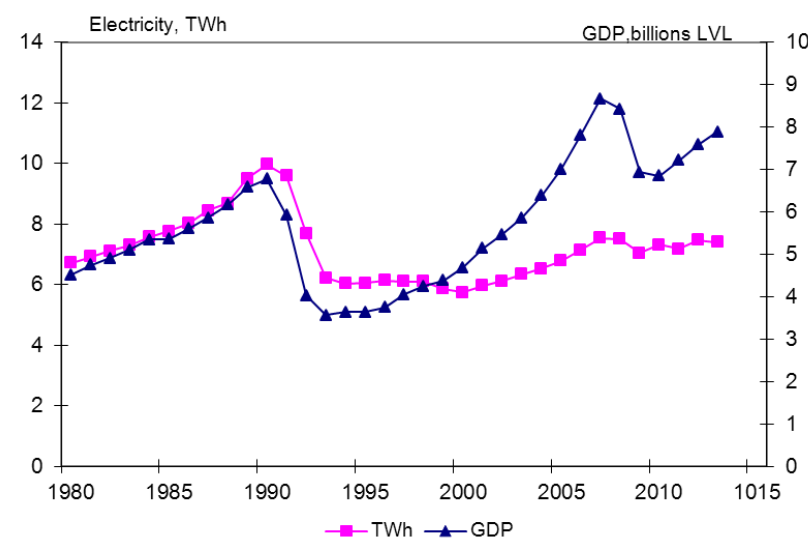

Fig. 2. The Latvian electricity consumption and GDP changes.

In the time span up to 1990 the forecasted and actual consumption in general followed the GDP growth with a high correlation coefficient. In all the elaborated forecasts a pronouncedly rapid growth in the electricity consumption was shown (see Fig. 1). 
After the restoration of the Latvian independence the electricity consumption decreased almost proportionally to the GDP falling rate. This fast "collapse" lasted until 1992, when a start was made for the structural re-organization of the Latvian economy and its stabilization. In the following decade (till 2002) at a minor GDP growth the electricity consumption almost did not rise, with variations of about $6 \pm 0.3 \mathrm{TWh}$. After this time span, up to the financial \& economic crisis the GDP grew by $120 \%$, while the electricity consumption - only by $\sim 20 \%$. All the consumption forecasts made till 2005 in practice do not coincide with actual consumption after that year; this is mainly explained by instability in the GDP growth.

After 2002 in Latvia a new period began - that of changes in the economic structure when a noticeable GDP growth took place, which was not followed by the rise in electricity consumption (see Fig. 2). It could therefore be concluded that the structural changes in economy during the post-socialism period affected positively the total consumption of electricity owing to better efficiency of its utilization.

\section{COMPARISON WITH THE ELECTRICITY CONSUMPTION IN EU STATES}

After the end of cold war, by 2004 the European Union was extended at the cost of East- and Central-Europe states. These - like Latvia - also were postsocialistic countries where similar structural economic changes occurred. Therefore, it is useful to compare the consumption changes in Latvia and the mentioned countries with those in West-European states. For the comparison, the data of EURELECTRIC statistics working group were used. These data were generalized by the leading energy experts from European states $[4,5]$.

Methodically, at the generalization the European states were divided into three groups: West-European, Central-European, and East-European.

The West-European states ( $81 \%$ of the total European population) are Germany, Spain, France, England, Italy, Austria, Belgium, Denmark, Finland, Greece, Ireland, Netherland, Portugal, and Sweden.

The Central-European states (12\% of the total European population) are the Czech Republic, Hungary, Poland, Slovenia and Slovakia.

The East-European states (7\% of the total European population) are Bulgaria, Estonia, Lithuania, Latvia, and Romania (smaller countries are not taken into account).

For each group of states the average electricity consumption from 1980 to 2010 is shown in Table 3 along with the planned by experts for 2020 .

Electricity consumption, TWh, in different groups of EU states

Table 3

\begin{tabular}{|l|c|c|c|c|c|}
\hline & $\mathbf{1 9 8 0}$ & $\mathbf{1 9 9 0}$ & $\mathbf{2 0 0 0}$ & $\mathbf{2 0 1 0}$ & $\mathbf{2 0 2 0}$ \\
\hline West-European states & 1489 & 1932 & 2461 & 2693 & 2785 \\
\hline Central-European states & 217 & 252 & 255 & 279 & 335 \\
\hline East-European states & 122 & 139 & 99 & 111 & 148 \\
\hline
\end{tabular}


Assuming the electricity consumption in 1990 to be $100 \%$ for each group of the states, the characteristics of its growth were obtained. The relative changes in electricity consumption for these groups are shown together in Fig. 3. It could be seen that in West-European countries no significant changes in consumption occurred after 1990, since there was no structural re-organization of economy.

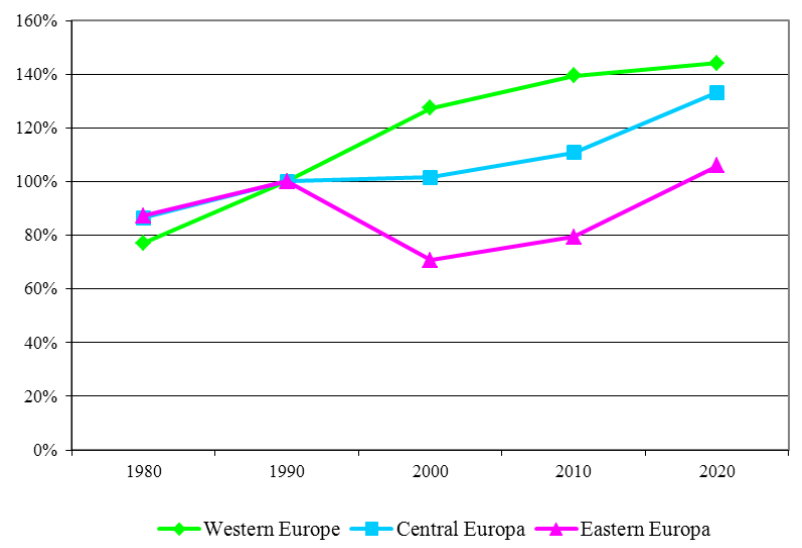

Fig. 3. Changes of electricity consumption in Europe Union.

The greatest differences were in the East-European countries where deep structural changes in economy occurred - and are going on.

In the EU states a sharp difference in consumption is observed for the major consumers' groups: industry, services, and households - more than $90 \%$ of the electricity consumed in a state. To gain an impression about these differences, in Fig. 4 the Latvian data are compared with those for two other state groups Denmark (West Europe) and Slovenia (Central Europe). Slovenia was chosen since its population of 1.96 mill. is almost the same as in Latvia. Denmark, in turn, possesses - similar to Latvia - a large park of generating capacities based on renewable energy sources.

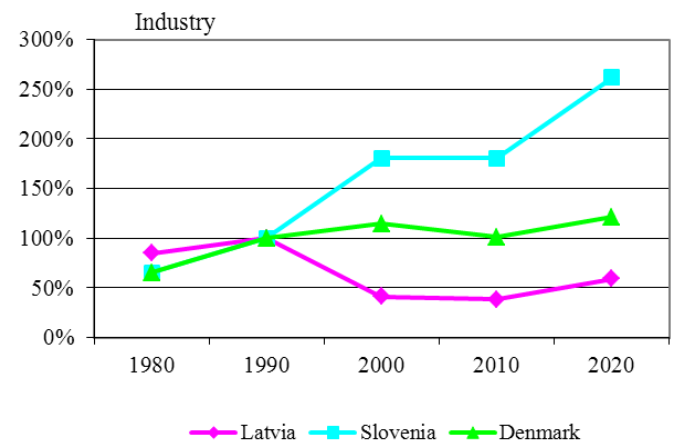

Fig. 4. Comparison of electricity consumption by the industry sectors of Latvia.

In Fig. 4 it is seen that in Denmark after 1990 practically no electricity consumption growth occurred. In turn, Latvia and Slovenia differ much in this 
regard. This means that the structural changes in the economies of these countries are dissimilar, and are going on. In Slovenia - as in other states of Central Europe the structural economic changes proceed much faster.

In the service sector, for all the three states a rapid growth in the electricity consumption is observed. From 1990 to 2000, Latvia and Slovenia experienced stagnation (Fig. 5).

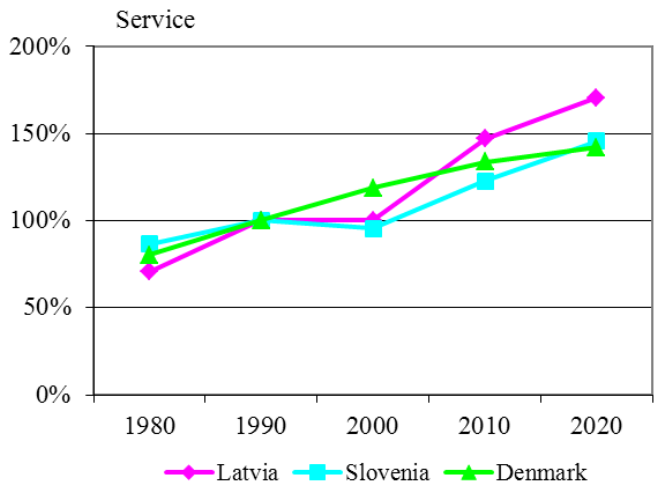

Fig. 5. Comparative electricity consumption by the service sectors of Latvia.

Curves of the type were obtained for the household sectors of the mentioned three countries (Fig. 6).

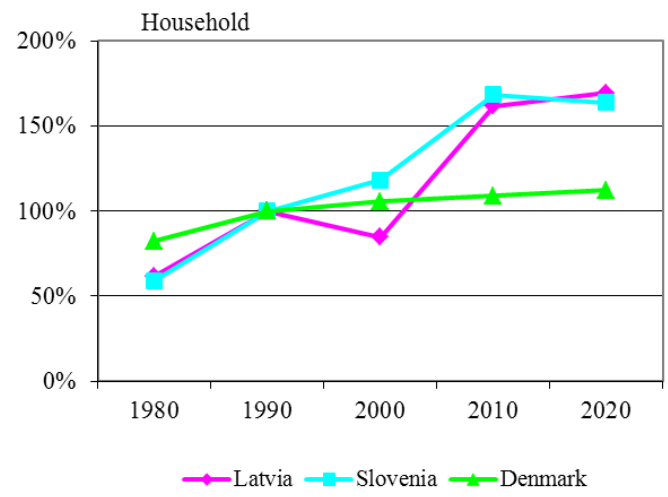

Fig. 6. Comparative electricity consumption by the household sectors.

As seen in Fig. 6, changes in the electricity consumption by Danish households are only minor, reaching certain saturation. As planned in Latvia and Slovenia, such saturation is to be reached there by 2020 .

In Denmark the relevant indices for three groups of consumers reached stability and definite regularity. Analysis of the Latvian and Slovenian data shows that from 1900 to 2010 noticeable changes in these groups took place, which is connected with structural economic re-organization. Statistical data for the time span 2010-2013 show deceleration in such changes. 


\section{COMPARISON OF ELECTRICITY CONSUMPTION INDICES}

The basic indices used at composing the forecasts of electricity consumption are as follows.

1. Electricity consumption per capita: $\mathrm{kWh} /$ capita.

2. Electricity consumption per GDP unit: $\mathrm{kWh} / €-G D P$.

3. GDP per capita $-€$-GDP/capita.

4. Electricity consumption structure: losses at energy transformation (heatelectricity), self-consumption by power plants, transmission and distribution losses, end consumption [6].

In the analysis, we have employed the first three basic indices, which reflect the current situation and determine the most significant changes in the electric energy consumption [5, 6]. For consideration the time span 1990-2010 was chosen, when in ten EU states the structural changes in economy took place. The relevant data are presented in Table 4, with the Latvian indices shown separately.

Comparison of the basic electricity consumption indices

Table 4 in EU states and in Latvia (1990-2010)

\begin{tabular}{|c|c|c|c|c|c|c|c|c|c|}
\hline & & 1990 & & & 2010 & & & $\begin{array}{l}\text { Changes } \\
1990 \text { to }\end{array}$ & 2010 \\
\hline & GDP & $\begin{array}{l}\text { popu- } \\
\text { lation }\end{array}$ & Energy & GDP & $\begin{array}{l}\text { popu- } \\
\text { lation }\end{array}$ & Energy & GDP & $\begin{array}{l}\text { popu- } \\
\text { lation }\end{array}$ & Energy \\
\hline & billion $€$ & million & TWh & billion $€$ & million & TWh & $\%$ & $\%$ & $\%$ \\
\hline $\begin{array}{l}\text { West- } \\
\text { European } \\
\text { states }\end{array}$ & 8391 & 361 & 1927 & 11101 & 392 & 2728 & $32 \%$ & $9 \%$ & $42 \%$ \\
\hline $\begin{array}{l}\text { Central- } \\
\text { European } \\
\text { states }\end{array}$ & 307 & 66 & 265 & 556 & 66 & 279 & $81 \%$ & $0 \%$ & $5 \%$ \\
\hline $\begin{array}{l}\text { East- } \\
\text { European } \\
\text { states }\end{array}$ & 82 & 38 & 132 & 115 & 34 & 103 & $41 \%$ & $-10 \%$ & $-22 \%$ \\
\hline Eu 24 & 8780 & 465 & 2323 & 11772 & 492 & 3110 & $34 \%$ & $6 \%$ & $34 \%$ \\
\hline Latvia & $9.87 \%$ & $2.66 \%$ & $10.00 \%$ & $12.40 \%$ & $2.15 \%$ & $7.30 \%$ & $0.26 \%$ & $-0.19 \%$ & $-0.27 \%$ \\
\hline
\end{tabular}

In Table 4 it is seen that in the West-European states the electricity consumption increased by $42 \%$, whereas in East-European states it decreased by $22 \%$. At the same time, the population in the former states increased by $9 \%$ while in the latter - it decreased by $10 \%$. As regards the GDP growth, in the CentralEuropean states it was considerably higher than in West Europe. Also, this indicator - in East-European states total - was greater than in the West. This means that the economic changes that occurred there were positive. In Latvia these indices were very moderate. 
The situation in the energy and economy spheres are pronouncedly characterized by specific indices derived from the basic ones: the electricity consumption per capita ( $\mathrm{kWh} / \mathrm{capita})$; the electricity consumption per GDP unit $(\mathrm{kWh} / €-G D P)$ which characterizes the effectiveness of electricity utilization and partially - the industrial structure in the state; GDP per capita GDP/capita) which characterizes the national economy's effectiveness. The specific values calculated based on relevant analysis are shown in Table 5.

Comparison of EU and Latvian specific indices for 1990-2010

Table 5

\begin{tabular}{|l|c|c|c|c|c|c|c|c|c|}
\hline & \multicolumn{3}{|c|}{1990.} & \multicolumn{3}{c|}{2010.} & \multicolumn{3}{c|}{$\begin{array}{c}\text { Changes \% } \\
\text { from 1990 to 2010 }\end{array}$} \\
\cline { 2 - 11 } & $\begin{array}{l}\text { TWh/ } \\
\text { capita }\end{array}$ & $\begin{array}{c}\text { GDP/ } \\
\text { capita }\end{array}$ & $\begin{array}{c}\text { TWh/ } \\
\text { GDP }\end{array}$ & $\begin{array}{c}\text { TWh/ } \\
\text { capita }\end{array}$ & $\begin{array}{c}\text { GDP/ } \\
\text { capita }\end{array}$ & $\begin{array}{c}\text { TWh/ } \\
\text { GDP }\end{array}$ & $\begin{array}{c}\text { TWh/ } \\
\text { capita }\end{array}$ & $\begin{array}{c}\text { GDP/ } \\
\text { capita }\end{array}$ & $\begin{array}{c}\text { TWh/ } \\
\text { GDP }\end{array}$ \\
\hline West-European states & 5340 & 23.3 & 0.23 & 6965 & 28.3 & 0.25 & $30 \%$ & $22 \%$ & $7 \%$ \\
\hline Central-European states & 4005 & 4.6 & 0.86 & 4213 & 8.4 & 0.50 & $5 \%$ & $81 \%$ & $-42 \%$ \\
\hline East-European states & 3460 & 2.1 & 1.62 & 3010 & 3.4 & 0.90 & $-13 \%$ & $57 \%$ & $-45 \%$ \\
\hline EU-24 & 4996 & 18.9 & 0.26 & 6319 & 23.9 & 0.26 & $26 \%$ & $27 \%$ & $0 \%$ \\
\hline & 3759 & 3.7 & 1.01 & 3395 & 5.8 & 0.59 & $-10 \%$ & $55 \%$ & $-42 \%$ \\
\hline Latvia & & & & & & & & & \\
\hline
\end{tabular}

Analysis of the specific indices shows that in the time span of 1990-2010 the electricity consumption per capita noticeably increased in West-European countries (30\%) while in the East-European ones it decreased. In Latvia the $10 \%$ consumption fall is observed, with the population decreased $19 \%$ in the same time period.

The specific index GDP/capita, which characterizes the structural changes in a state's economy, during these 20 years increased by $22 \%$ in West-European states, while in East-European ones the growth was greater - 57\% (in Latvia 55\%).

The specific index TWh/GDP, which characterizes the effectiveness of electricity utilization per GDP unit, in West-European states is negative (increased $7 \%$ ), whereas in East-European states this effectiveness grew considerably $-45 \%$ (in Latvia 42\%).

In 1990, in Central- and East-European states the common and specific indices as compared with those in West-European states were much worse, since the economic structure was there for a long time based on the energy-consuming industry and the agriculture; obsolete technologies and equipment were employed; prices of energy resources were particularly low; appropriate control over the consumed energy was absent (commercial losses); real initiatives as to the improvement of energy intensity of the end consumption were deficient, etc.

In the last 20 years improvement of the specific indices has been observed in Central- and East-European states, which is evidence for positive structural changes in their economies; however, much has yet to be done to ensure that these indices approach the level of those in West Europe. 


\title{
6. CONCLUSIONS
}

1. Forecasting of electricity consumption in Latvia at the end of $20^{\text {th }}$ century and up to 2005 was unsuccessful. In forecasts the economic structural changes which are going on - were not taken into account.

2. In Latvia - being a post-socialistic state - the economic structural changes have not yet stabilized, especially in industry. This should be taken into account at forecasting the electricity consumption.

3. Particular attention at forecasting should also be given to two other major consumers' groups: services and households.

4. The electricity consumption criteria differ markedly in EU states; therefore, each state - or a group of states - has to use its own criteria.

5. At working out the Latvian electricity consumption criteria it is useful to consider those adopted in East-European states as the closest patterns.

6. The changes in GDP are highly sensitive to the political and economic crises, which considerably change the actual electricity consumption.

7. The data obtained in this study on the Latvian electricity consumption and the tendencies in their changes could be of help when composing the long-term electricity forecasts.

\section{REFERENCES}

1. State Energy Programme 1992 of the Latvian Republic. Manager: Z. Blumbergs, Publisher TILTS (in Latvian).

2. Jorgen Fenhann. (Aug. 1992). Energy Conservation Potentials in Lithuania and Latvia. Riso National Laboratory (Denmark), Roskilde Riso-M-2941(EN).

3. Statistics and prospects for the European electricity sector (2008). EURPROG, $36^{\text {th }}$ ed-n.

4. Statistical Yearbooks of Latvia, Central Statistical Bureau, $1991-2011$.

5. EURELECTRIC Power Statistics \& Trends, full report (2013).

6. Galinis, A., \& Miškinis, V. (2000). Energy Consumption Trends in Lithuania. Latv. J. Phys. Tech. Sci., (2), $34-44$.

\section{LATVIJAS ELEKTROENERĢIJAS PATĒRIN̦A PROGNOŽU ANALĪZE}

\author{
M. Balodis, V. Gavars, J. Andersons
}

\section{Kopsavilkums}

Rakstā apskatītas elektroenerǵijas patēriņa izmaiņas, kas saistītas ar Latvijas postsociālisma perioda ekonomikas strukturālām izmaiñām. Rakstā dota Latvijas galveno elektroenerǵijas patēriņa indikatoru analīze, lietojot īpašu pieeju Rietumeiropas, Centrāleiropas un Austrumeiropas valstu indikatoru salīdzinājumu. Analizēts periods no 1990. gada līdz 2010. gadam. Salīdzināti Eiropas valstu grupu īpatnējie elektroenerǵijas patēriņa indikatori un noskaidrotas to atšķirības un izmaiņu tendences. Noteiktas elektroenerğijas patēriņa izmaiņu tendences Latvijāa Dotas rekomendācijas par šo indikatoru izmantošanu elektroenerǵijas patēriņa prognozēšanā.

07.05.2014. 